\begin{tabular}{|l|l|l||}
\hline \multicolumn{2}{|c|}{ PublisherInfo } \\
\hline \hline PublisherName & $:$ & BioMed Central \\
\hline \hline PublisherLocation & $:$ & London \\
\hline \hline PublisherImprintName & $:$ & BioMed Central \\
\hline \hline
\end{tabular}

\title{
Turning rats into robots
}

\begin{tabular}{|l|l|l||}
\hline \multicolumn{2}{|c|}{ ArticleInfo } \\
\hline \hline ArticleID & $:$ & 4467 \\
\hline \hline ArticleDOI & $:$ & $10.1186 /$ gb-spotlight-20020502-02 \\
\hline \hline ArticleCitationID & $:$ & spotlight-20020502-02 \\
\hline \hline ArticleSequenceNumber & $:$ & 133 \\
\hline \hline ArticleCategory & $:$ & Research news \\
\hline \hline ArticleFirstPage & $:$ & 1 \\
\hline \hline ArticleLastPage & $:$ & 2 \\
\hline \hline & & RegistrationDate : 2002-5-2 \\
\hline ArticleHistory & $:$ & OnlineDate \\
\hline \hline ArticleCopyright & $:$ & BioMed Central Ltd2002-5-2 \\
\hline \hline ArticleGrants & $:$ & \\
\hline \hline ArticleContext & $:$ & 130593311 \\
\hline \hline
\end{tabular}




\section{Jonathan B Weitzman}

Email: jonathanweitzman@hotmail.com

Laboratory animals can be trained to perform simple tasks in response to external cues (such as specific noises) or rewards (such as food). In the May 2 Nature, Talwar et al. describe a learning procedure based on brain microstimulation rather than external cues (Nature 2002, 417:37-38). They implanted stimulating electrodes in the medial forebrain bundle (MFB) or the somatosensory cortical, to mimic rewards or cues, respectively. They strapped a remote-control microstimulator backpack to each animal. In this way the operator could train the rats from as much as $500 \mathrm{~m}$ away by delivering stimulus pulses. MFB stimuli were used to drive forward locomotion and could guide the rats through pipes and around mazes. Talwar et al. propose that such 'virtual' learning methods provide a powerful tool to and understanding of the neurophysiology of learning and behavior. They add that this approach "could allow a guided rat to function as a both a mobile robot and a biological sensor".

\section{References}

1. Nature, [http://www.nature.com] 